\title{
New Frontiers in Intravesical Therapies and Drug Delivery
}

\author{
Antonella Giannantoni ${ }^{a, *}$, Savino M. Di Stasi ${ }^{b}$, Michael B. Chancellor ${ }^{c}$, \\ Elisabetta Costantini ${ }^{a}$, Massimo Porena $^{a}$ \\ a Department of Urology, University of Perugia, Perugia, Italy \\ b Department of Urology, "Tor Vergata" University of Rome, Rome, Italy \\ ${ }^{c}$ McGowan Institute of Regenerative Medicine, University of Pittsburgh School of Medicine, Pittsburgh, PA, United States
}

\section{Article info}

Article history:

Accepted August 16, 2006

Published online ahead of

print on August 30, 2006

\section{Keywords:}

Electric current

Intravesical drug

administration

Permeability

Sustained delivery

\begin{abstract}
Objectives: The intravesical route permits site-specific delivery of drugs with a reduced side-effect profile as compared to oral delivery systems, either by avoiding first-pass metabolism or by obtaining a local effect. We investigated mechanisms related to urothelium permeability and new physical and chemical developments in intravesical drug delivery that potentially permit successful treatment of several bladder dysfunction.

Methods: A literature review.

Results: Pharmacologic agents increasing urothelial permeability and useful for clinical purposes have been described, such as dimethylsulfoxide, protamine sulphate, chitosan, and nystatin. Among physical approaches, electromotive drug administration appears to be more effective than intravesical passive diffusion in delivering drugs through the urothelium into deeper layers of the bladder. Experimental and clinical reports demonstrated that electric current significantly increases the transport of local anaesthetics, mytomicin C, oxybutynin, resiniferatoxin, epinephrine, and dexamethasone. Among new chemical approaches, cell-penetrating peptides posses the ability to translocate macromolecular drugs across membranes of urothelial cells. The therapeutic benefits of sustained delivery afforded by thermosensitive hydrogel, which forms a depot for hydrophilic and hydrophobic drugs, have been demonstrated by delivering anti-inflammatory drugs. Liposomes improve the aqueous solubility of several hydrophobic drugs such as taxol, amphotericin, and capsaicin.

Conclusions: Electromotive drug administration, new in situ delivery systems, and bioadhesive liposomes may make it possible to extend intravesical therapy and drug administration to many bladder diseases. Research to expand knowledge of the chemical and physical properties of the bladder and processes regulating drug transport across biologic membranes is needed to make this a reality.

(c) 2006 European Association of Urology. Published by Elsevier B.V. All rights reserved.

* Corresponding author. Department of Urology, University of Perugia, Policlinico

Monteluce, Via Brunamonti 51, 06122 Perugia, Italy. Tel. +39 075 5783979;

Fax: +39075 5726123 .

E-mail address: agianton@libero.it (A. Giannantoni).
\end{abstract}




\section{Introduction}

The direct administration of drug solutions into the bladder overcomes systemic adverse effects of drugs used for bladder disease. Commonly used for the treatment of superficial bladder cancer, intravesical drug administration, for example, oxybutynin, has also been used to treat neurogenic detrusor overactivity [1]. The variability of the results obtained in different clinical studies with intravesical oxybutynin can be attributed to several factors related to the properties of the urothelium as well as the characteristics of the therapeutic agents.

Recent observations of several receptors for different neurotransmitters (cholinergic, adrenergic, purinergic, and vanilloid receptors) at the level of the urothelial cells suggest that the target sites for pharmacologic modulation of bladder dysfunction should be readily available. In any event, the ideal chemical and physical conditions for each instilled drug solution must still be standardised. Urine is frequently hypertonic and differs markedly with respect to blood potassium and $\mathrm{pH}$. Changes in intravesical ions, osmolality, and $\mathrm{pH}$ can alter urothelial permeability, increasing or decreasing drug penetration into the bladder wall.

Furthermore, it seems that a crucial point to obtain successful drug penetration is the vehicle of the drug solution to increase urothelial permeability. Normal saline, ethanol at different concentrations, glucidic solvents, or liposomes with hydrogel, have been used for capsaicin and resiniferatoxin (RTX) intravesical delivery, with different success rates [2-5].

As things currently stand, we do not know the best vehicle for each intravesical drug nor do we know the ideal bladder conditions to perform useful intravesical treatment. Indeed, a better knowledge of urothelial permeability and of new systems of delivery could help to optimise intravesical treatments.

This review examines the mechanisms underlying drug transport into the bladder wall and discusses exciting new frontiers for intravesical therapy.

\section{Bladder urothelium: permeability and drug diffusion}

The main function of the urinary bladder is to store urine while maintaining the composition of the urine similar to that produced by the kidneys. The urothelium allows the urinary bladder to minimise alterations in the composition of the urine.
Urothelial cells have different properties to perform this function. First of all, the urothelium should expose a minimum surface to intravesical volume to avoid large movements of urine components across the bladder wall. The geometry of the bladder, which resembles a sphere, is ideal for obtaining a minimum epithelial surface area with respect to urine volume. Thus, the amount of movement of substances between the urine and blood is reduced. Urothelial cells should be impermeable to all substances present in the urine or blood. Movement across the urothelial cells occurs via two parallel pathways: the "transcellular pathway" (through the cells) and the "paracellular pathway" (through the tight junctions and lateral intercellular spaces) [7]. Tight junctions and cell membranes should be impermeable to urine or blood components, as well as to any drug contained in both compartments. Modifications of either cellular or tight junction permeability alter the efficacy of the barrier properties of the urothelium.

\section{Passive permeability}

For prolonged periods, the mammalian bladder is able to maintain large gradients for water, small nonelectrolytes, ions, protons, and ammonium between the urine it stores and blood. It is well known that the bladder has a small but finite passive permeability to most substances (electrolytes and nonelectrolytes) found in the urine and blood [9]. It is possible to measure the ion permeability of an epithelium by calculating the transepithelial electric resistance, which is caused by the parallel arrangement of cell resistance and tight junction resistance [10]. Based on the magnitude of this resistance, epithelial cells are divided into two categories: leaky and tight epithelial cells. The bladder epithelium is considered a tight epithelium [11], which has the highest recorded transepithelial resistance of all epithelia measured to date. The lack of "uroplakins" or urothelial plaques (protein particles packed hexagonally in the apical surface of the urothelium) does not affect the function of the tight junctions between umbrella cells, but does increase urea and water permeability [8].

In essence, the apical membrane of the bladder urothelium contributes $80 \%$ of the resistance to water flow of the epithelium as well as $>95 \%$ of the resistance to fluxes of urea, ammonia, and protons. If there is appreciable permeation of these substances through the tight junctions, then the apical membrane provides an even higher proportion of the resistance across the epithelium [12]. 


\section{The "blood-urine barrier"}

An essential requirement for normal bladder function is that urine components should not jeopardise the barrier properties of the bladder [6]. Changes within the physiologic range for urine $\mathrm{pH}$ or calcium or urea concentrations do not alter the barrier function of the urothelium, as determined from measurements of the transepithelial resistance. Consequently, acid $\mathrm{pH}$, low $\mathrm{Ca}^{++}$, or high urea increase the ion permeability of the urothelium [8]. In experimental studies, urine seems to be able to influence the volume-pressure response of the bladder; bladder capacity can be reduced by administering intravesical solutions of isotonic $\mathrm{KCl}$, hypertonic $\mathrm{NaCl}$, and pH 5 [9]. It can be increased by administration of hypotonic $\mathrm{NaCl}$, isotonic mannitol, and pH 8 [9]. Furthermore, extracellular $\mathrm{K}^{+}$and hyperosmolality directly depolarise smooth muscle cells and generate increased activity of the detrusor, whereas hypo-osmolality produces opposite changes [9].

\section{Agents that alter urothelial permeability}

Several pharmacologic agents, which increase bladder urothelial permeability and can be used for clinical purposes, have been described.

A number of nonphysiologic factors cause alterations of the urothelial barrier function. Bacterial products, such as amphotericin B, nystatin, polymyxin $B$, and possibly $\beta$-hemolysin, as well as positively charged proteins released from eosinophils and found in sperm (histones and protamine), increase the ion permeability of the urothelium by interacting with the apical membrane.

Acetate, propionate, butyrate, or succinate at $\mathrm{pH}$ 4.4, but not at $\mathrm{pH}$ 5.0, also alter the transepithelial permeability of rabbit urothelium [9]. The increase in transepithelial permeability due to volatile fatty acids is rapid (minutes) and is due, in part, to an increase in the permeability of the apical membrane to sodium and chloride [13].

\subsection{Chitosan}

Chitosan is a polysaccharide composed of glucosamine and $\mathrm{N}$-acetylglucosamine. It is regarded as a biocompatible, biodegradable, and nontoxic polymer. Chitosan can induce desquamation of pig urothelium, which removes all diffusion barriers: glycosaminoglycans, membrane plaques, and tight junctions of umbrella cells. This ability has been proven in vitro on nasal, buccal, vaginal, and urinary bladder mucosa of different animals, thus making this polymer a promising agent in the development of controlled drug delivery systems [14].

\subsection{Antibiotics}

Nystatin and gramicidin eliminate the apical membrane as a resistive element for water diffusion. Nystatin is incorporated into the lipid bilayers of sterol-containing biologic membranes and creates aqueous pores. This effect rapidly increases with the addition of the detergent Triton X-100 [15].

\subsection{Protamine sulphate}

An ideal model of urothelial injury would involve selective damage to the surface of urothelial or umbrella cells. On the basis of its potential to damage the surface glycosaminoglycan layer of urothelial cells, protamine sulphate (PS) has been instilled into bladders in vivo and the effects on bladder function have been evaluated $[16,17]$. It was demonstrated that exposure to PS in vivo causes a clear-cut disruption of the bladder permeability barrier, which starts within $1 \mathrm{~h}$ of exposure and recovers during days $2-5$ [18]. PS bladder damage can be avoided by the addition of intraperitoneal melatonin or intravesical defibrotide $[19,20]$.

\subsection{Dimethyl sulfoxide}

Widely used to treat interstitial cystitis, dimethyl sulfoxide (DMSO) is a solvent with anti-inflammatory and bacteriostatic activity; it produces analgesia and nerve blockade, diuresis, cholinesterase inhibition, vasodilation, and muscle relaxation. DMSO also has the unique capability to penetrate living tissues without causing significant damage. It has been used to enhance bladder absorption of chemotherapeutic agents such as cisplatin, pirarubicin, and doxorubicin $[21,22]$. In addition, DMSO is approved by the US Food and Drug Administration for the treatment of interstitial cystitis and up to $50 \%$ (vol/vol) DMSO can safely be instilled in the bladder of patients.

\section{Recent developments in physical approaches}

Drugs absorption through the bladder wall and drug concentrations at the target site (detrusor) are important determinants of efficacy, but passive diffusion (PD) of drugs across the urothelium is complex and not easily defined. 
Many factors, including pressure and concentration gradients, time of exposure, partition coefficient, molecular weight and chemical structure, $\mathrm{pH}$ degree of ionisation, and urinary output rate, interact to produce different transport rates.

It has been observed that recruitment of electrokinetic forces accelerates drug administration rates across biologic membranes and into underlying tissues [23]. The term "electromotive drug administration" (EMDA) describes the transport of all water-soluble drugs under the influence of an electric field and, unlike PD, is most effective when dealing with an ionised drug, where the rate of drug transport is proportional to the intensity of the applied current, which largely overrides all other variables $[23,24]$.

The idea of using electric current to allow transcutaneous drug penetration can probably be attributed to the work done by Veratti in 1747 [25]. The concept of iontophoresis was first described in the mid-18th century. However, it was not until Leduc's experimentation in 1908 that researchers realised the importance of the differences between positive and negative ions and adopted this technique for therapeutic uses. In recent years, iontophoresis has been used for local anaesthesia of the skin [26], to administer corticosteroids to joints and tendons involved in inflammatory processes [27], and for regular transcutaneous administration of drugs [28].

EMDA has been recently applied in the treatment of bladder pathologies and dysfunctions. Laboratory and clinical studies have been conducted on intravesical electromotive delivery of oxybutynin [29,30], mitomycin C (MMC) [31-33], RTX [34,35], verapamil and dexamethasone [36], bethanecol [37], and lidocaine and epinephrine [38] (Tables 1 and 2).

Laboratory studies have been performed, first of all, to identify a sensitive method to determine tissue concentrations of different drugs after either PD or electromotive administration (Table 1).

Massoud et al. found that high-performance liquid chromatography (HPLC), equipped with a diode-array spectrophotometric detector, an electrochemical detector and reversed-phase column,

Table 1 - Laboratory studies of drug administration by EMDA or passive delivery

\begin{tabular}{|c|c|c|c|c|}
\hline Authors [ref] & Aims to assess & Tissue/material & Results & Advantages/problems \\
\hline Lugnani et al. [24] & $\begin{array}{l}\text { Lidocaine + epinephrine } \\
\text { penetration with EMDA }\end{array}$ & $\begin{array}{l}\text { Cadaveric human } \\
\text { bladder }\end{array}$ & $\begin{array}{l}\text { Staining extends into the } \\
\text { muscolaris in all bladders }\end{array}$ & $\begin{array}{l}\text { EMDA may have } \\
\text { applications to treat } \\
\text { bladder diseases }\end{array}$ \\
\hline Gurpinar et al. [25] & $\begin{array}{l}\text { Methylene blue penetration } \\
\text { with EMDA }\end{array}$ & Dog bladder & $\begin{array}{l}\text { Significant submucosal and } \\
\text { muscolaris methylene blue } \\
\text { penetration }\end{array}$ & $\begin{array}{l}\text { EMDA may have } \\
\text { applications } \\
\text { to treat bladder } \\
\text { diseases }\end{array}$ \\
\hline Di Stasi et al. [41] & $\begin{array}{l}\text { (a) MMC concentrations after } \\
\text { passive diffusion or EMDA } \\
\text { (b) Effects of EMDA on tissue } \\
\text { viability and on MMC structure }\end{array}$ & Human bladder & $\begin{array}{l}\text { EMDA/MMC reduces } \\
\text { variability in drug } \\
\text { delivery rate }\end{array}$ & $\begin{array}{l}\text { Tissue undamaged and } \\
\text { viable, no modification } \\
\text { in drug structure }\end{array}$ \\
\hline Di Stasi et al. [40] & $\begin{array}{l}\text { Oxybutynin concentrations after } \\
\text { both passive delivery or EMDA }\end{array}$ & Human bladder & $\begin{array}{l}\text { After EMDA: mean } \\
\text { oxybutynin tissue } \\
\text { concentrations } \\
\text { significantly higher }\end{array}$ & $\begin{array}{l}\text { Tissue undamaged and } \\
\text { viable, no modification } \\
\text { in drug structure }\end{array}$ \\
\hline Di Stasi et al. [42] & $\begin{array}{l}\text { MMC concentration-depth profiles } \\
\text { after passive diffusion or EMDA }\end{array}$ & Human bladder & $\begin{array}{l}\text { EMDA significantly } \\
\text { enhances MMC transport } \\
\text { into all bladder wall layers }\end{array}$ & $\begin{array}{l}\text { Tissue undamaged and } \\
\text { viable, no modification } \\
\text { in drug structure }\end{array}$ \\
\hline Massoud et al. [39] & $\begin{array}{l}\text { Oxybutynin extraction and } \\
\text { determination by HPLC }\end{array}$ & Human bladder & $\begin{array}{l}\text { EMDA significantly } \\
\text { enhances oxybutynin } \\
\text { penetration }\end{array}$ & $\begin{array}{l}\text { Simple and cost } \\
\text { effective; no internal } \\
\text { standard required }\end{array}$ \\
\hline Di Stasi et al. [38] & $\begin{array}{l}\text { (a) Stability of lidocaine and } \\
\text { epinephrine over time } \\
\text { (mass spectrometry) } \\
\text { (b) Transport rates with } \\
\text { passive diffusion or EMDA }\end{array}$ & Pig bladder & $\begin{array}{l}\text { Lidocaine and } \\
\text { epinephrine remain } \\
\text { stable for } 1 \mathrm{~d} \text {; EMDA } \\
\text { accelerates lidocaine } \\
\text { and epinephrine transport }\end{array}$ & $\begin{array}{l}\text { In vitro results support } \\
\text { clinical studies }\end{array}$ \\
\hline Di Stasi et al. [35] & $\begin{array}{l}\text { Stability of RTX stock } \\
\text { solution by HPLC }\end{array}$ & Plastic material/glass & $\begin{array}{l}\text { RTX stock solutions: } \\
\text { better stability if } \\
\text { stored at } \leq 4{ }^{\circ} \mathrm{C} \text { in the dark }\end{array}$ & $\begin{array}{l}\text { Material for RTX } \\
\text { storage is not } \\
\text { important }\end{array}$ \\
\hline Di Stasi et al. [34] & $\begin{array}{l}\text { RTX concentrations of } \\
\text { after passive delivery or EMDA }\end{array}$ & Pig bladder & $\begin{array}{l}\text { RTX bladder concentrations } \\
\text { significantly higher }\end{array}$ & $\begin{array}{l}\text { Large coefficient of } \\
\text { variation with both } \\
\text { techniques }\end{array}$ \\
\hline
\end{tabular}


was a useful method to determine tissue concentrations of oxybutynin [39]. The procedure was then applied for tissue extraction and the determination of other agents (Table 1).

The objectives of experimental studies were also to analyse the effects of electric current both on bladder tissues and on the chemical structure of the drug being used. Di Stasi et al. observed that EMDA did not alter the chemical structure of RTX, lidocaine and epinephrine, oxybutynin, or MMC and did not induce any damage to the exposed bladder tissues $[34,38,40-42]$, thus making this method a promising tool for the treatment of detrusor overactivity and superficial bladder cancer and for inducing local anaesthesia. Furthermore, through in vitro studies the authors demonstrated that EMDA significantly increased the transport rates of several drugs into the bladder wall, as compared to simple PD. Two recent laboratory studies investigated both the transport rates of RTX into pig bladder wall after either PD or EMDA and the best conditions for the stability of RTX stock solutions [34,35]. These authors showed that the application of electric current significantly reduced the variability in transport rates of RTX as compared to PD and that glass storage in the dark and at low temperatures did not alter the stability of the drug $[34,35]$. These results could allow better results with RTX intravesical treatment.

From a clinical standpoint (Table 2), EMDA has been demonstrated to significantly increase the transport rates of several drugs into the bladder wall, as compared to simple PD [32,43-45]. Stenzl et al. found that five of six patients were tumour free after a follow-up of 10-16 mo, after electromotive administration of $\delta$-aminolevulinic acid ( $\delta$-ALA) solution [44]. In this study, $\delta$-ALA was used for the photodynamic diagnosis and therapy of superficial bladder tumours. The response rate in high-risk superficial bladder cancer was improved with increased bladder uptake of MMC following electromotive administration [32]. Intravesical electromotive administration of both 5 and $15 \mathrm{mg}$ oxybutynin significantly increased cystometric bladder capacity and significantly reduced the first volume for the onset of uninhibited detrusor contractions, and duration and maximum pressure of these contractions, in patients with neurogenic detrusor overactivity $[29,30]$. Clinical reports demonstrated that intravesical EMDA of local anaesthetics produced sufficient anaesthesia to allow transurethral resection of bladder tumours $[45,46]$, to perform botulinum toxin A injections into the detrusor muscle [47], to administer intravesical capsaicin [48], and to determine cystodistention in the treatment of refractory interstitial cystitis and chronic noninfectious cystitis [49-51].

\subsection{Side-effects}

Fatal side-effects have never been reported during or after treatment with EMDA. Hinkel and Pannek reported systemic neurologic alterations after EMDA in two older patients treated for chronic noninfectious cystitis, probably related to epinephrine systemic absorption [52]. No clinical evidence of lidocaine toxicity has been reported, and serial serum lidocaine levels measured in a few patients were innocuous [46]. No haematologic toxicity was observed after application of MMC by PD or EMDA $[31,32]$, and no systemic side-effects were observed after oxybutynin $15 \mathrm{mg}$ with EMDA application [30]. The most frequently reported side-effect is the appearance of a transient skin erythema at the site of abdominal electrode or a tingling sensation on the abdomen during treatment (Table 2).

\subsection{Costs}

It has been reported that, compared to spinal or general anaesthesia, the local anaesthesia induced by lidocaine with EMDA saves around 15\% of the costs [47]. This treatment modality allows clinicians to perform bladder distention also in an office setting, with equivalent results to distention under general anaesthesia and potentially less morbidity and lower costs $[53,54]$. The cost per patient was about \$146 Cdn less with electromotive intravesical lidocaine than with conventional general/spinal anaesthesia [45]. Overall, the cost of the technique includes purchasing a generator ( $\cong$ Euro 2500.00), a specially designed electrode ( $\cong$ Euro 250.00), and anaesthetics and other medications. The current generator can usually be used for at least 100 treatments before needing replacement or repair.

\section{Recent developments in chemical approaches}

A number of substances have been developed to increase drug transport across the bladder wall. Sasaki reported that intravesical instillation of saponin before administering anticancer drugs (4'O-tetrahydropyranyldoxorubicin [THP]) can cause vacuolisation and swelling of superficial cells, and the concentration of THP in bladder tissues was significantly higher than that of untreated animals. In any case, no difference was found in plasma $[55,56]$. 
Table 2 - Clinical trials of intravesical drug administration by EMDA or passive delivery

\begin{tabular}{|c|c|c|c|c|c|}
\hline Authors [ref] & $\begin{array}{c}\text { Trials } \\
\text { (no. of patients) }\end{array}$ & Indications & $\begin{array}{l}\text { Intravesical drug/ } \\
\text { surgical procedure }\end{array}$ & Results & Side-effects \\
\hline Lugnani et al. [24] & Controlled (22) & $\begin{array}{l}\text { Bladder anaesthesia } \\
\text { before surgery }\end{array}$ & Lidocaine and epinephrine/EMDA & Pain in $16 / 22$ patients & $\begin{array}{l}\text { In all patients: } \\
\text { transient erythema } \\
\text { of abdominal skin }\end{array}$ \\
\hline Gurpinar et al. [25] & Prospective (6) & $\begin{array}{l}\text { Refractory interstitial } \\
\text { cystitis }\end{array}$ & $\begin{array}{l}\text { Lidocaine and epinephrine + } \\
\text { cystodistention }\end{array}$ & $\begin{array}{l}\text { Symptoms improved } \\
\text { in } 4 \text { patients }\end{array}$ & $\begin{array}{l}\text { Tingling sensation on } \\
\text { the abdominal skin }\end{array}$ \\
\hline Stenzl et al. [44] & Prospective (6) & $\begin{array}{l}\text { Superficial bladder cancer: } \\
\text { to evaluate the effects } \\
\text { of } \delta \text {-ALA in photodynamic } \\
\text { diagnosis and therapy }\end{array}$ & $\begin{array}{l}\text { PD/ } \delta \text {-ALA vs. EMDA/ } \delta \text {-ALA } \\
\text { and photodynamic therapy }\end{array}$ & $\begin{array}{l}5 \text { patients were tumor free } \\
\text { for to up } 16 \mathrm{mo}\end{array}$ & $\begin{array}{l}\text { No complications } \\
\text { occurred }\end{array}$ \\
\hline Riedl et al. [49] & Prospective (17) & Noninfectious chronic cystitis & $\begin{array}{l}\text { Lidocaine and dexamethasone + } \\
\text { cystodistention }\end{array}$ & $\begin{array}{l}\text { No pain in } 11 \text { patients; partial } \\
\text { resolution in } 4\end{array}$ & $\begin{array}{l}\text { No complications } \\
\text { occurred }\end{array}$ \\
\hline Rosamilia et al. [51] & Prospective (21) & $\begin{array}{l}\text { Refractory interstitial } \\
\text { cystitis }\end{array}$ & $\begin{array}{l}\text { Lidocaine and dexamethasone }+ \\
\text { cystodistention }\end{array}$ & $\begin{array}{l}\text { No pain in } 25 \% \text { of patients } \\
\text { at } 6 \mathrm{mo} \text { and in } 63 \% \text { at } 2 \mathrm{mo}\end{array}$ & $\begin{array}{l}\text { No complications } \\
\text { occurred }\end{array}$ \\
\hline Fontanella et al. [46] & Prospective (91) & $\begin{array}{l}\text { Bladder and urethral } \\
\text { anaesthesia before surgery }\end{array}$ & EMDA/lidocaine and adrenaline & No pain in 111 interventions & $\begin{array}{l}\text { Transient erythema } \\
\text { of abdominal skin }\end{array}$ \\
\hline Brausi et al. [43] & $\begin{array}{l}\text { Prospective } \\
\text { multicenter } \\
\text { controlled (28) }\end{array}$ & Superficial bladder cancer & $\begin{array}{l}\text { Passive/MMC (13 patients) } \\
\text { vs. EMDA/MMC (15 patients) }\end{array}$ & $\begin{array}{l}\text { EMDA/MMC: } \\
\text { CR: } 41 \% \text { vs. } 41.6 \% ; \\
\text { less recurrence, } \\
\text { longer disease-free interval }\end{array}$ & $\begin{array}{l}\text { After EMDA/MMC: } \\
\text { severe chemical } \\
\text { cystitis in } 2 / 15 \\
\text { patients; cutaneous } \\
\text { rush in } 1 / 15\end{array}$ \\
\hline Dasgupta et al. [48] & Prospective (8) & $\begin{array}{l}\text { Refractory neurogenic } \\
\text { detrusor overactivity }\end{array}$ & $\begin{array}{l}\text { EMDA/lidocaine and epinephrine } \\
\text { (before intravesical capsaicin) }\end{array}$ & $\begin{array}{l}\text { Successful } \\
\text { CR: } 75 \% \text { of patients; increase in } \\
\text { functional bladder capacity } \\
\text { from } 3 \text { to } 8 \text { mo }\end{array}$ & No complications \\
\hline Riedl et al. [50] & Prospective (13) & $\begin{array}{l}\text { Refractory interstitial } \\
\text { cystitis }\end{array}$ & $\begin{array}{l}\text { EMDA/lidocaine and } \\
\text { dexamethasone + } \\
\text { cystodistention }\end{array}$ & $\begin{array}{l}\text { No pain in } 62 \% \text { of patients } \\
\text { for } 4.5 \text { mo; mean bladder } \\
\text { capacity increased by } 166 \%\end{array}$ & $\begin{array}{l}\text { Transient erythema } \\
\text { of abdominal skin }\end{array}$ \\
\hline Jewett et al. [45] & $\begin{array}{l}\text { Prospective } \\
\text { multicenter (94) }\end{array}$ & $\begin{array}{l}\text { Bladder cancer, } \\
\text { BPH, interstitial } \\
\text { cystitis }\end{array}$ & $\begin{array}{l}\text { No anaesthesia (18 patients) } \\
\text { vs. EMDA/lidocaine before } \\
\text { bladder biopsy ( } 27 \text { patients); } \\
\text { EMDA/lidocaine for: } \\
\text { transuretral resection } \\
\text { of bladder cancer ( } 43 \text { patients), } \\
\text { hydrodistension and BPH } \\
\text { ( } 6 \text { patients) }\end{array}$ & No pain in EMDA groups & $\begin{array}{l}\text { Tingling sensation } \\
\text { during treatment; } \\
\text { mucosal blanching } \\
\text { at the bladder neck }\end{array}$ \\
\hline Colombo et al. [33] & Prospective (80) & $\begin{array}{l}\text { Superficial } \\
\text { bladder cancer }\end{array}$ & $\begin{array}{l}\text { Passive/MMC ( } 36 \text { patients) } \\
\text { vs. MMC/thermochemotherapy } \\
\text { ( } 29 \text { patients) vs. EMDA/MMC } \\
\text { (15 patients) }\end{array}$ & $\begin{array}{l}\text { CR: } \\
\text { (a) Passive/MMC: } 27 \% \\
\text { (b) Thermochemtherapy/ } \\
\text { MMC: } 40 \% \\
\text { (c) EMDA/MMC: } 66 \%\end{array}$ & $\begin{array}{l}\text { Local toxicity } \\
\text { more severe after } \\
\text { thermochemotherapy }\end{array}$ \\
\hline Di Stasi et al. [29] & Prospective (10) & $\begin{array}{l}\text { Refractory neurogenic } \\
\text { detrusor overactivity }\end{array}$ & $\begin{array}{l}\text { Oral oxybutynin } \\
\text { vs. passive/oxybutynin } \\
\text { vs. EMDA/oxybutynin + } \\
\text { pharmacokinetic } \\
\text { studies (oxybutynin) }\end{array}$ & $\begin{array}{l}\text { After EMDA/oxybutynin: } \\
\text { significant improvements } \\
\text { in urodynamics }\end{array}$ & $\begin{array}{l}\text { Transient erythema } \\
\text { of abdominal skin } \\
\text { in most patients }\end{array}$ \\
\hline
\end{tabular}




\section{Table 2 (Continued)}

\begin{tabular}{|c|c|c|c|c|c|}
\hline Authors [ref] & $\begin{array}{c}\text { Trials } \\
\text { (no. of patients) }\end{array}$ & Indications & $\begin{array}{l}\text { Intravesical drug/ } \\
\text { surgical procedure }\end{array}$ & Results & Side-effects \\
\hline Di Stasi et al. [30] & Prospective (12) & $\begin{array}{l}\text { Refractory neurogenic } \\
\text { detrusor overactivity }\end{array}$ & $\begin{array}{l}\text { Oral oxybutynin } \\
\text { vs. passive/oxybutynin } \\
\text { vs. EMDA/oxybutynin + } \\
\text { pharmacokinetic } \\
\text { studies (oxybutynin } \\
\text { and } N \text {-desethyloxybutynin) }\end{array}$ & $\begin{array}{l}\text { After EMDA/oxybutynin: } \\
\text { significant improvements } \\
\text { in urodynamics }\end{array}$ & $\begin{array}{l}\text { Transient erythema } \\
\text { of abdominal skin in } \\
\text { most patients }\end{array}$ \\
\hline Riedl et al. [37] & Prospective (25) & $\begin{array}{l}\text { Detrusor } \\
\text { hypocontractility }\end{array}$ & EMDA/bethanecol & $\begin{array}{l}\text { EMDA/bethanecol predicts } \\
\text { success of oral therapy in } \\
86 \% \text { of patients }\end{array}$ & $\begin{array}{l}\text { Bladder discomfort } \\
\text { and pain in few cases }\end{array}$ \\
\hline Di Stasi et al. [31] & $\begin{array}{l}\text { Multicentre } \\
\text { randomised } \\
\text { controlled (108) }\end{array}$ & $\begin{array}{l}\text { Superficial } \\
\text { bladder cancer }\end{array}$ & $\begin{array}{l}\text { Passive/MMC ( } 36 \text { patients) } \\
\text { vs. EMDA/MMC ( } 36 \text { patients) } \\
\text { vs. passive/BCG ( } 36 \text { pts) }\end{array}$ & $\begin{array}{l}\text { CR: } \\
\text { (a) Passive/MMC: } 28 \% \\
\text { (b) EMDA/MMC: } 53 \% \\
\text { (c) BCG: } 56 \%\end{array}$ & $\begin{array}{l}\text { No complications } \\
\text { with EMDA }\end{array}$ \\
\hline Schurch et al. [47] & Prospective (38) & $\begin{array}{l}\text { Refractory neurogenic } \\
\text { detrusor overactivity }\end{array}$ & $\begin{array}{l}\text { Passive/lidocaine }+ \\
\text { Botox (10 patient) } \\
\text { vs. EMDA/lidocaine }+ \\
\text { Botox (28 patients) }\end{array}$ & $\begin{array}{l}\text { Mean pain score: } 4.0 \text { vs. } 0.5 \text {, } \\
\text { respectively }\end{array}$ & $\begin{array}{l}\text { After EMDA/lidocaine: } \\
\text { slight or no pain } \\
\text { during Botox } \\
\text { injections }\end{array}$ \\
\hline Hinkel et al. [52] & Case report (1) & $\begin{array}{l}\text { Chronic noninfectious } \\
\text { cystitis }\end{array}$ & $\begin{array}{l}\text { EMDA/lidocaine + epinephrine + } \\
\text { dexamethasone }\end{array}$ & Success & No complications \\
\hline Rose et al. [54] & Prospective (21) & $\begin{array}{l}\text { Refractory interstitial } \\
\text { cystitis }\end{array}$ & $\begin{array}{l}\text { Passive/lidocaine + cystodistention } \\
\text { (10 patients) vs. EMDA/lidocaine } \\
\text { (11 patients) + } \\
\text { cystodistention, in the office }\end{array}$ & $\begin{array}{l}\text { After EMDA/lidocaine: } 135 \% \\
\text { increase in bladder capacity }\end{array}$ & Failure \\
\hline Rose et al. [53] & Retrospective (21) & $\begin{array}{l}\text { Refractory interstitial } \\
\text { cystitis }\end{array}$ & $\begin{array}{l}\text { EMDA with cystodistention in the } \\
\text { office vs. general anaesthesia }\end{array}$ & No significant difference & Pain persistence \\
\hline Di Stasi et al. [32] & $\begin{array}{l}\text { Prospective } \\
\text { randomised }\end{array}$ & $\begin{array}{l}\text { High-risk superficial } \\
\text { bladder cancer }\end{array}$ & Passive/BCG vs. BCG + EMDA/MMC & $\begin{array}{l}\text { BCG + EMDA/MMC longer } \\
\text { disease-free interval, less } \\
\text { recurrence, progression, } \\
\text { and disease-specific mortality }\end{array}$ & $\begin{array}{l}\text { No systemic } \\
\text { complications }\end{array}$ \\
\hline
\end{tabular}

EMDA = electromotive drug administration; $\delta$-ALA $=\delta$-aminolevulinic acid; $\mathrm{PD}=$ passive diffusion; $\mathrm{MMC}=$ mitomycin $\mathrm{C}$; $\mathrm{CR}=$ complete response; $\mathrm{BPH}=$ benign prostatic hyperplasia; BCG = bacillusCalmette-Guérin. 
Certain peptides called cell-penetrating peptides or protein transduction domains have been shown to posses the ability to translocate macromolecular drugs across the blood-brain barrier and membranes of other cells [57]. However, these peptides are not cell selective and thus represent a poor choice for systemic use.

One of the authors of the present study (M.B.C.) examined the effect of short-length transactivators of transcription peptides, deriving from immunodeficiency virus, for the intravesical administration of macromolecular drugs such as peptide nucleic acids (PNAs). PNAs have been used for their "antisense" effect in various studies; in other words, they bind to RNA and completely block transcription [58]. PNAs show superior binding properties and higher stability in biologic fluids such as urine, over a wide $\mathrm{pH}$ range, as compared to traditional oligonucleotides and ribozymes [59].

\subsection{Sustained drug delivery}

Sustained intravesical delivery of drugs can ensure the continuous presence of the drug in the bladder without needing intermittent catheterisation, and drug concentration in the bladder would be constant without any peaks and valleys. It is also plausible to expect increased efficacy with increased duration of direct contact between the drug and the abnormal urothelium [60].

A simple and sensible approach for sustained intravesical drug delivery is prolonged infusion into the bladder. This technique has often been applied to achieve slow and sustained release of drugs inside the bladder. Prolonged instillation of RTX was recently demonstrated as a feasible procedure for treating interstitial cystitis [61]. RTX was infused through a suprapubic 5F mono-pigtail catheter for 10 $\mathrm{d}$ at the flow rate $25 \mu \mathrm{l} / \mathrm{h}$ with the help of an infusion pump. Patients were evaluated $30 \mathrm{~d}$ after the end of infusion and after $3 \mathrm{mo}$. A 30\% decrease in frequency and a 3-fold reduction of nocturia was observed, with a significant reduction of pelvic pain for at least 6 mo after the end of infusion. A similar approach was previously applied for local therapy of prostaglandins in the treatment of cyclophosphamideinduced cystitis in patients $[62,63]$. A $100-\mathrm{ml}$ irrigation of $5 \mu \mathrm{g} / \mathrm{ml}$ prostaglandin $\mathrm{E}_{2}\left(\mathrm{PGE}_{2}\right)$ into the bladder for $3 \mathrm{~h}$ completely freed a 40 -yr-old patient of all symptoms within $24 \mathrm{~h}$ [64].

Forming a drug depot inside the bladder appears to be an attractive option over prolonged infusion. Aqueous solutions of poly(ethylene glycol-b-[DLlactic acid-co-glycolic acid]-b-ethylene glycol) (PEGPLGA-PEG) triblock copolymers form a free-flowing solution at room temperature and become a viscous gel at body temperature of $37^{\circ} \mathrm{C}$ [65]. Its formulation does not require organic solvent, and the products from bioerosion of the biocompatible polymer are nontoxic PEG, glycolic acid, and lactic acid [66]. Thermosensitive hydrogel formed by PEG-PLGA-PEG has been used for in situ gel formation for a depot of hydrophobic and hydrophilic drugs following subcutaneous administration in rats [67]. The triblock copolymer was used for sustaining the residence time of hydrophobic drugs in rat bladder after its instillation at room temperature. The kinetics of drug excretion were studied by fluorescence measurement of urine after instilling fluorescein isothiocyanate-loaded hydrogel. The increased urine concentration over a period of time implies increased penetration into the bladder tissue. The therapeutic benefit of sustained delivery afforded by thermosensitive hydrogel was demonstrated by delivering misoprostol, an anti-inflammatory drug. It was able to protect the bladder against cyclophosphamide-induced cystitis [68].

\subsection{Liposomes}

Liposomes were first studied in England in 1961 by Bangham [69] and, since then, they have become a versatile tool of study in biology, biochemistry, and medicine. Liposomes are artificial spherical vesicles consisting of an aqueous core enclosed in one or more phospholipid layers, used as drug carriers and loaded with a great variety of molecules such as small drug molecules, proteins, nucleotides, and even plasmids [70]. Previously, liposomes were shown to improve the aqueous solubility of hydrophobic drugs such as paclitaxel (Taxol) and amphotericin; a recent report by the laboratory of one of the authors in the United States discussed the use of liposomes as vehicles for capsaicin and evaluated their potential as a vehicle for intravesical delivery in rats [71]. Liposomes were able to deliver capsaicin with efficacy similar to that of ethanolic saline, but toxicity to the bladder was drastically reduced [72].

Liposomes are versatile drug delivery vehicles due to the flexibility of their compositions. Liposomes were used for intracellular delivery of anticancer drugs and biologics into the bladder cancer cell line. Use of multilamellar liposomes proved favourable in cell culture studies and the antiproliferative capacity of interferon $\alpha$ (IFN- $\alpha$ ) in resistant bladder cancer cell lines was improved by using liposomes as a delivery vehicle. Instillation of liposomes encapsulated radiolabelled IFN- $\alpha$ or radiolabelled liposomes into mouse bladder was able to 
achieve localised therapy with negligible penetration to other organs.

Earlier it was reported that liposomes can form a film on the cell surface and have been tested as possible therapeutic agents to promote wound healing. Such reports prompted evaluation of empty liposomes devoid of any drug in a rat model of bladder hyperactivity. Liposomes alone were able to partially reverse the high urinary frequency induced by PS/KCl. These observations suggested that liposomes might enhance the barrier properties of a dysfunctional uroepithelium and increase resistance to irritant penetration.

\section{Conclusions}

The lower urinary tract is ideally suited for minimally invasive intravesical therapy that would limit the risk of systemic side-effects. Although treatment with intravesical passive delivery of drugs is commonly used today in patients on intermittent catheterisation, new physical approaches such as EMDA or in situ delivery systems and bioadhesive liposomes may expand intravesical therapy and drug administration to many bladder diseases. New agents modulating bladder neurotransmitters and neuroreceptors are being discovered, and they may be appropriate for advanced intravesical therapy. Research to expand the knowledge of chemical and physical properties of the bladder and processes regulating drug transport across biologic membranes is needed to make this a reality.

\section{References}

[1] Brendler TB, Appell RA, Lopez MA, et al. Pharmacokinetic evaluation of intravesical oxybutynin: bolus and continuous delivery. J Urol 2001;165:252 (abstract no. 1039).

[2] Lazzeri M, Spinelli M, Zanollo L, Turini D. Intravesical vanilloids and neurogenic incontinence: ten years experience. Urol Int 2004;72:145-9.

[3] Giannantoni A, Di Stasi SM, Stephen RL, et al. Intravesical capsaicin versus resiniferatoxin in patients with detrusor hyperreflexia: a prospective randomized study. J Urol 2002;167:1710-4.

[4] de Seze M, Wiart L, de Seze MP, et al. Intravesical capsaicin versus resiniferatoxin for the treatment of detrusor hyperreflexia in spinal cord injured patients: a doubleblind, randomized, controlled study. J Urol 2004;171: 251-5.

[5] Tyagi P, Chancellor MB, Li Z, et al. Urodynamic and immunohistochemical evaluation of intravesical capsaicin delivery using thermosensitive hydrogel and liposomes. J Urol 2004;171:483-9.
[6] Parsons CL, Lilly JD, Stein P. Epithelial dysfunction in nonbacterial cystitis (interstitial cystitis). J Urol 1991; 145:732-5.

[7] Lewis SA. Epithelial electrophysiology. In: Wills NK, Reuss L, Lewis SA, editors. Epithelial transport: a guide to methods and experimental analysis. London: Chapman \& Hall; 1996. p. 93-117.

[8] Lewis SA, Diamond JM. $\mathrm{Na}^{+}$transport by rabbit urinary bladder, a tight epithelium. J Membr Biol 1976;28:1-40.

[9] Ping H, Meyers S, Liang F, et al. Role of membrane proteins in permeability barrier function: uroplakin ablation elevates urothelial permeability. Am J Physiol Renal Physiol 2002;283:200-7.

[10] Negrete HO, Lavelle JP, Berg J, Lewis SA, Zeidel ML. Permeability properties of the intact mammalian bladder epithelium. Am J Physiol 1996;271:886-94.

[11] Lewis SA. Everything you wanted to know about the bladder epithelium but were afraid to ask. Am J Physiol Renal Physiol 2000;278:867-74.

[12] Hohlbrugger G, Lentsch P. Intravesical ions, osmolality and $\mathrm{pH}$ influence the volume pressure response in the normal rat bladder and this is more pronounced after DMSO. Eur Urol 1985;11:127-30.

[13] Mann FC, Magoun JAH. Absorption from the urinary bladder. Am J Med Sci 1923;166:96-106.

[14] Kerec M, Bogataj M, Veranic P, Mrhar A. Permeability of pig urinary bladder wall: the effect of chitosan and the role of calcium. Eur J Pharm Sci 2005;25:113-21.

[15] Holz R, Finkelstein A. The water and nonelectrolyte permeability induced in thin lipid membranes by the polyene antibiotics nystatin and amphotericin B. J Gen Physiol 1970;56:124-45.

[16] Chuang YC, Yoshimura N, Huang CC, Chaing PH, Chancellor MB. Intravesical botulinum toxin A administration produces analgesia against acetic acid induced bladder pain responses in rats. J Urol 2004;172:1529-32.

[17] Vemulakonda VM, Somogyi GT, Kiss S, Salas NA, Boone $\mathrm{TB}$, Smith CP. Inhibitory effects of intravesically applied botulinum toxin a in chronic bladder inflammation. J Urol 2005;173:621-4.

[18] Lavelle J, Meyers S, Ramage R, et al. Bladder permeability barrier: recovery from selective injury of surface epithelial cells. Am J Physiol Renal Physiol 2002;283:242-53.

[19] Cetinel S, Ercan F, Sirvanci S, et al. The ameliorating effect of melatonin on protamine sulfate induced bladder injury and its relationship to interstitial cystitis. J Urol 2003;169: 1564-8.

[20] Aydin H, Ercan F, Cetinel S, San T. Morphological examination of the effects of defibrotide on experimentally induced bladder injury and its relation to interstitial cystitis. Urol Res 2001;29:263-71.

[21] Melchior D, Packer CS, Johnson TC, Kaefer M. Dimethyl sulfoxide: does it change the functional properties of the bladder wall? J Urol 2003;170:253-8.

[22] See WA, Xia Q. Regional chemotherapy for bladder neoplasms using continuous intravesical infusion of doxorubicin: impact of concomitant administration of dimethyl sulfoxide on drug absorption and antitumor activity. J Natl Cancer Inst 1992;84:510-5. 
[23] Phipps JB, Padmanabhan RV, Lattin GA. Iontophoretic delivery of model inorganic and drug ions. J Pharm Sci 1989;78:365-9.

[24] Lugnani F, Mazza G, Cerulli N, Rossi C, Stephen RL. Iontophoresis of drugs in the bladder wall: equipment and preliminary studies. Artif Organs 1993;17:8-17.

[25] Gurpinar T, Truong LD, Wong HY, Griffith DP. Electromotive drug administration to the urinary bladder: an animal model and preliminary results. J Urol 1996;156:1496-501.

[26] Turnell WJ. Therapeutic action of constant current. Proc R Soc Med 1921;14:41-52.

[27] Sloan JB, Soltani K. Iontophoresis in dermatology. J Am Acad Dermatol 1986;15:617-84.

[28] Glass JM, Stephen RL, Jacobson SC. The quantity and distribution of radiolabeled dexamethasone delivered to tissue by iontophoresis. Int J Dermatol 1980;19:519-24.

[29] Di Stasi SM, Giannantoni A, Vespasiani G, et al. Intravesical electromotive administration of oxybutynin in patients with detrusor hyperreflexia unresponsive to standard anticholinergic regimens. J Urol 2001;165:491-8.

[30] Di Stasi SM, Giannantoni A, Navarra P, et al. Intravesical oxybutynin: mode of action assessed by passive diffusion and electromotive administration with pharmacokinetics of oxybutynin and N-desethyl oxybutynin. J Urol 2001;166: 2232-6.

[31] Di Stasi SM, Giannantoni A, Stephen RL, et al. Intravesical electromotive mitomycin $C$ versus passive transport mitomycin C for high risk superficial bladder cancer: a prospective randomized study. J Urol 2003;170:777-82.

[32] Di Stasi SM, Giannantoni A, Giurioli A, et al. Sequential BCG and electromotive mitomycin versus BCG alone for high-risk superficial bladder cancer: a randomized controlled trial. Lancet Oncol 2006;7:43-51.

[33] Colombo R, Brasi M, Da Pozzo L, et al. Thermo-chemotherapy and electromotive drug administration of mitomycin $\mathrm{C}$ in superficial bladder cancer eradication. A pilot study on marker lesions. Eur Urol 2001;39:95-100.

[34] Di Stasi SM, Giannantoni A, Massoud R, et al. Comparative bladder wall tissue levels of resiniferatoxin. In: Proc. Abstract Book of the ICS 34th Annual meeting, Paris, 25-27 August 2004 (abstract no. 577).

[35] Di Stasi S, Giannantoni A, Massoud R, Navarra P, Vespasiani G, Porena M, Stephen R. Stability of resiniferatoxin stock solution. Eur Urol Suppl 2004;3(2):106 (abstract no. 414).

[36] Di Stasi SM, Giannantoni A, Stephen RL, et al. A prospective randomized study using transdermal electromotive administration of verapamil and dexamethasone for Peyronie's disease. J Urol 2004;171:1605-8.

[37] Riedl CR, Daha LK, Knoll M, Pflueger H. Betanechol in the restitution of the acontractile detrusor: a prospective, randomized, double-blind, placebo-controlled study. Neurourol Urodyn 2002;21:376 (abstract no. 71A).

[38] Di Stasi SM, Giannantoni A, Navarra P, et al. The stability of lidocaine and epinephrine solutions exposed to electric current and comparative administrations rates of the two drugs into pig bladder wall. Urol Res 2003;31:169-76.

[39] Massoud R, Federici G, Casciani S, et al. Extraction and determination of oxybutynin in human bladder samples by reversed-phase high-performance liquid chromatography. J Chromatogr B 1999;734:163-7.

[40] Di Stasi SM, Giannantoni A, Massoud R, Cortese C, Vespasiani G, Micali F. Electromotive administration of oxybutynin into the human bladder wall. J Urol 1997; 158:228-33.

[41] Di Stasi SM, Vespasiani G, Giannantoni G, Massoud R, Dolci S, Micali F. Electromotive delivery of mitomycin C into the human bladder wall. Cancer Res 1997;57:87580.

[42] Di Stasi SM, Giannantoni A, Massoud R, et al. Electromotive versus passive diffusion of mitomycin $C$ into human bladder wall: concentration-depth profiles studies. Cancer Res 1999;59:4912-8.

[43] Brausi M, Campo B, Pizzocaro G, et al. Intravesical electromotive administration of drugs for treatment of superficial bladder: a comparative phase II study. Urology 1998;51:506-9.

[44] Stenzl A, Eder I, Kostron H, Klocker H, Bartsch G. Electromotive diffusion (EMD) and photodynamic therapy with delta-aminolevulinic acid (delta-ALA) for superficial bladder cancer. J Photochem Photobiol B 1996;36:233-6.

[45] Jewett MAS, Valiquette L, Sampson HA, Katz J, Fradet Y, Redelmeier DA. Electromotive drug administration of lidocaine as an alternative anesthesia for transurethral surgery. J Urol 1999;482-5.

[46] Fontanella UA, Rossi CA, Stephen RL. Bladder and urethral anaesthesia with electromotive drug administration (EMDA): a technique for invasive endoscopic procedures. Br J Urol 1997;79:414-20.

[47] Schurch B, Reitz A, Tenti G. Electromotive drug administration of lidocaine to anesthetize the bladder before botulinum-A toxin injections into the detrusor. Spinal Cord 2004;42:338-41.

[48] Dasgupta P, Fowler CJ, Hoverd P, et al. Does electromotive drug administration (EMDA) with lignocaine before intravesical capsaicin confer benefit? J Urol 1997;157:186 (abstract no. 724).

[49] Riedl C, Knoll M, Plas E, Stephen RL, Pfluger H. Intravesical electromotive drug administration for the treatment of non-infectious chronic cystitis. Int Urogynecol J Pelvic Floor Dysfunct 1997;8:134-7.

[50] Riedl C, Knoll M, Plas E, Pfluger H. Electromotive drug administration and hydrodistention for the treatment of interstitial cystitis. J Endourol 1998;12:269-72.

[51] Rosamilia A, Dwyer PL, Jbson J. Electromotive drug administration of lidocaine and dexamethasone followed by cystodistension in women with interstitial cystitis. Int Urogynecol J Pelvic Floor Dysfunct 1997;8:142-5.

[52] Hinkel A, Pannek J. Transient ischemic attack after electromotive drug administration for chronic non-infectious cystitis: report of two similar cases. Neurourol Urodyn 2004;23:180-2.

[53] Rose EA, Azevedo KJ, Payne CK. Office bladder distension with electromotive drug administration (EMDA) is equivalent to distension under general anesthesia. BMC Urol 2005;5:14-8.

[54] Rose AE, Payne CK, Azevedo K. Pilot study of the feasibility of in-office bladder distention using electromotive drug 
administration (EMDA). Neurourol Urodyn 2005;24:25460.

[55] Sasaki M, Hashimoto H, Yachiku S. Studies on enhancement of drug absorption through the bladder mucosa. Nippon Hinyokika Gakkai Zasshi 1994;85:1353-62.

[56] Hashimoto H, Yachiku S, Watanabe Y, et al. Postoperative intravesical installation of tetrahydropyranyl-adriamycin (THP) and cytosine arabinoside (CA) for superficial bladder cancer: clinical results of prophylactic effects on recurrence. Gan To Kagaku Ryoho 1994;21:833-8.

[57] Schwarze SR, Ho A, Vocero-Akbani A, Dowdy SF. In vivo protein transduction: delivery of a biologically active protein into the mouse. Science 1999;285:1569-72.

[58] Nielsen PE. Gene targeting using peptide nucleic acid. Methods Mol Biol 2005;288:343-58.

[59] Pooga M, Land T, Bartfai T, Langel U. PNA oligomers as tools for specific modulation of gene expression. Biomol Eng 2001;17:183-92.

[60] Frangos DN, Killion JJ, Fan D, et al. The development of liposomes containing interferon alpha for the intravesical therapy of human superficial bladder cancer. J Urol 1990;143:1252-6.

[61] Lazzeri M, Spinelli M, Beneforti P, Malaguti S, Giardiello G, Turini D. Intravesical infusion of resiniferatoxin by a temporary in situ drug delivery system to treat interstitial cystitis: a pilot study. Eur Urol 2004;45:98-102.

[62] Shurafa M, Shumaker E, Cronin S. Prostaglandin F2-alpha bladder irrigation for control of intractable cyclophosphamide-induced hemorrhagic cystitis. J Urol 1987;137: 1230-1.

[63] Trigg ME, O’Reilly J, Rummelhart S, Morgan D, Holida M, de Alarcon P. Prostaglandin E1 bladder instillations to control severe hemorrhagic cystitis. J Urol 1990;143:92-4.
[64] Miller LJ, Chandler SW, Ippoliti CM. Treatment of cyclophosphamide-induced hemorrhagic cystitis with prostaglandins. Ann Pharmacother 1994;28:590-4.

[65] Ronneberger B, Kao WY, Anderson JM, Kissel T. In vivo biocompatibility study of ABA triblock copolymers consisting of poly(L-lactic-co-glycolic acid) A blocks attached to central poly(oxyethylene) B blocks. J Biomed Mater Res 1996;30:31-40.

[66] Jeong B, Bae YH, Kim SW. Drug release from biodegradable injectable thermosensitive hydrogel of PEG-PLGAPEG triblock copolymers. J Control Release 2000;63: 155-63.

[67] Jeong B, Bae YH, Kim SW. In situ gelation of PEG-PLGA-PEG triblock copolymer aqueous solutions and degradation thereof. J Biomed Mat Res 2000;50:171-7.

[68] Tyagi P, Li Z, Chancellor MB, de Groat WC, Yoshimura N, Huang L. Sustained intravesical drug delivery using thermosensitive hydrogel. Pharm Res 2004;21:832-7.

[69] Bangham AD. A correlation between surface charge and coagulant action of phospholipids. Nature 1961;192: 1197-8.

[70] Johnson JW, Nayar R, Killion JJ, von Echenbach AC, Fidler IJ. Bindings of liposomes to human bladder tumor epithelial cell lines: implications for an intravesical drug delivery system for the treatment of bladder cancer. Sel Cancer Ther 1989;5:147-55.

[71] Tyagi P, Chancellor MB, Li Z, et al. Urodynamic and immunohistochemical evaluation of intravesical capsaicin delivery using thermosensitive hydrogel and liposomes. J Urol 2004;171:483-9.

[72] Fraser MO, Chuang YC, Tyagi P, et al. Intravesical liposome administration-a novel treatment for hyperactive bladder in the rat. Urology 2003;3:656-63.

\section{Editorial Comment \\ Karel Everaert, Department of Urology, \\ Ghent University Hospital, Belgium \\ karel.everaert@Ugent.be}

This comprehensive article on intravesical therapies reviews the less accessible, nonmedical literature for the urologist and links the information to clinical practice and empirical therapies for which I offer my congratulations. The physical and chemical properties of the urothelium are worth further study in the future and empirically found applications need confirmation in randomised trials so that a larger introduction into clinical practice is possible. Improving anaesthesia of the bladder is useful for general urologic practice. In functional urology, interstitial cystitis and the overactive bladder are demanding indications for any improvement in the intravesical route (botulinum toxin, resiniferatoxin, dimethyl sulfoxide, oxybutynin, etc). Electromotive drug administration (EMDA) is not routinely used in clinical practice and intraluminal drug delivery devices need confirmation in the literature along with pertinent indications. New chemical approaches are discussed but are still considered experimental. This review is hopefully the impetus for a large series of studies, publications, and new developments. 